\title{
DAMPAK PERSEPSI KONSUMEN TERHADAP MINAT BELI KONSUMEN BERBELANJA DI LOTTE MART GROSIR PEKANBARU
}

\author{
Nofrizal
}

\author{
Fakultas Ekonomi, Universitas Lancang Kuning
}

\begin{abstract}
ABSTRAK
Tujuan penelitian ini adalah untuk mengetahui pengaruh persepsi konsumen terhadap minat beli konsumen untuk berbelanja pada Lotte Grosir Pekanbaru serta apakah terdapat hubungan yang positif dan signifikan antar persepsi konsumen terhadap minat beli konsumen Lotte Grosir Pekanbaru. Objek penelitian ini adalah konsumen yang berbelanja di Lotte Grosir Pekanbaru dengan jumlah sampel sebanyak 95 orang responden menggunakan metode accidential sampling. Pengelolaan dan analisis data menggunakan analisis regresi linier berganda dengan program SPSS versi 23. Hasil penelitian diperoleh Secara simultan faktor persepsi (kelengkapan produk, harga, lokasi, pelayanan dan kenyamanan) berpengaruh secara signifikan terhadap minat beli konsumen Lotte Grosir Pekanbaru dengan nilai signifikan 0,000 <0,05. Secara parsial diketahui bahwa kelengkapan produk, harga, lokasi dan kenyamanan berpengaruh signifikan terhadap minat beli konsumen, sedangkan pelayanan tidak berpengaruh terhadap minat beli konsumen. Selanjutnya, nilai koefisien determinasi (R2) sebesar 0,930 atau 93,00\%. Hal ini menunjukkan bahwa kelima variabel bebas (kelengkapan produk, harga, lokasi, pelayanan dan kenyamanan) secara bersama-sama memberikan sumbangan/ pengaruh terhadap minat beli konsumen pada Lotte Grosir Pekanbaru. Adapun faktor persepsi yang paling besar pengaruhnya yaitu kelengkapan produk (X1).
\end{abstract}

Kata Kunci: pemasaran, persepsi konsumen, minat beli konsumen, pelayanan, pusat perbalanjaan.

\section{PENDAHULUAN}

Akhir-akhir ini perkembangan bisnis ritel mengalami pertumbuhan yang sangat pesat. Dengan banyaknya bisnis ritel modern seperti hypermarket, supermarket dan minimarket serta maraknya pembangunan mall atau pusat 
perbelanjaan di kota Pekanbaru membuat semakin ketatnya persaingan di dunia peritel (David, 2018). Selain pertumbuhan pusat-pusat perbelanjaan diatas dampak online market (Facebook dan Instagram) dan (E-Commerce) juga mempengaruhi kondisi Industri Ritel di Kota Pekanbaru, dimana konsumen dimudahankan dengan fasilitas Diskon, Kenyamanan, Variasi barang, dan Privasi terjaga (Aufa, 2014). Saat ini terdapat 10 E-Commerce terbesar di Indonesia yaitu Lazada Indonesia, MatahariMall, Blibli, Zalora Indonesia, JD Indonesia, Tokopedia, Elevenia, Shopee, Bukalapak, dan Qoo10 (Cahya, 2018). Sehingga dampak dari perkembangan ritel dan E-Commerce diatas sangat berpengaruh terhadap kondisi ritel di Kota Pekanbaru khususnya PT. Lotte Grosir Pekanbaru. Menurut data telah terjadi penurunan jumlah pelanggan dari tahun 2013-2018 sebesar $17 \%$ sedangkan capaian realisasi target penjualan rata-rata dari tahun 2013-2018 sebesar 66\% lihat Grafik 1 dan Grafik 2.

Berdasarkan Grafik 1 dan Grafik 2, menunjukkan bahwa pencapaian target penjualan yang ditentukan oleh Lotte Grosir Pekanbaru belum tercapai ditambah lagi data perkembangan konsumen yang cendrung mengalami penurunan setiap tahun. Oleh karena itu, Lotte Grosir Pekanbaru membutuhkan informasi penyebab belum tercapainya penjualan dan tren penurunan konsumen. Maka penelitian ini akan membantu Lotte mart dari melihat dari sisi persepsi konsumen terhadap minat beli konsumen sebagai bahan kajian untuk membantu Lotte Mart menyusun strategi pemasaran yang tepat sehingga dapat bertahan dan berkembang dimasa yang akan datang.

\section{Grafik 1}

Perkembangan Konsumen Lotte Mart Grosir Pekanbaru 2013-2018

\section{Perkembangan Konsumen tahun 2013-2018}

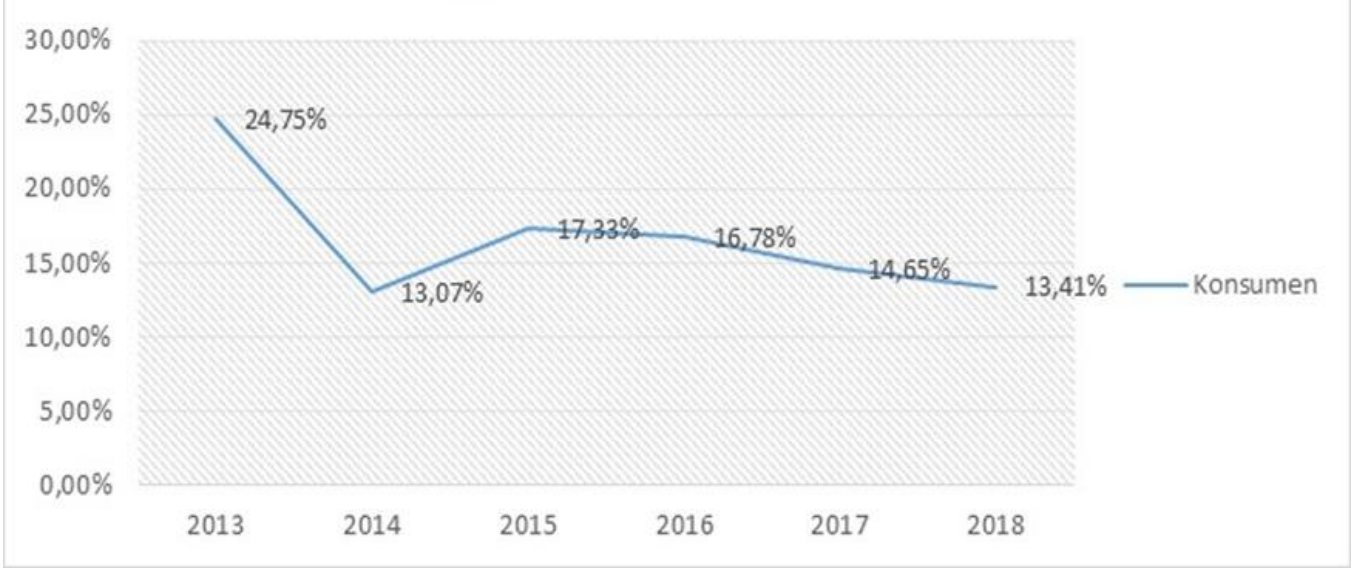




\title{
Grafik 2
}

\section{Target dan Realisasi Pendapatan Lotte Mart Grosir Pekanbaru 2013-2018}

\author{
Target dan Realisasi pendapatan Lotte Grosir Pekanbaru \\ Tahun 2013-2018
}

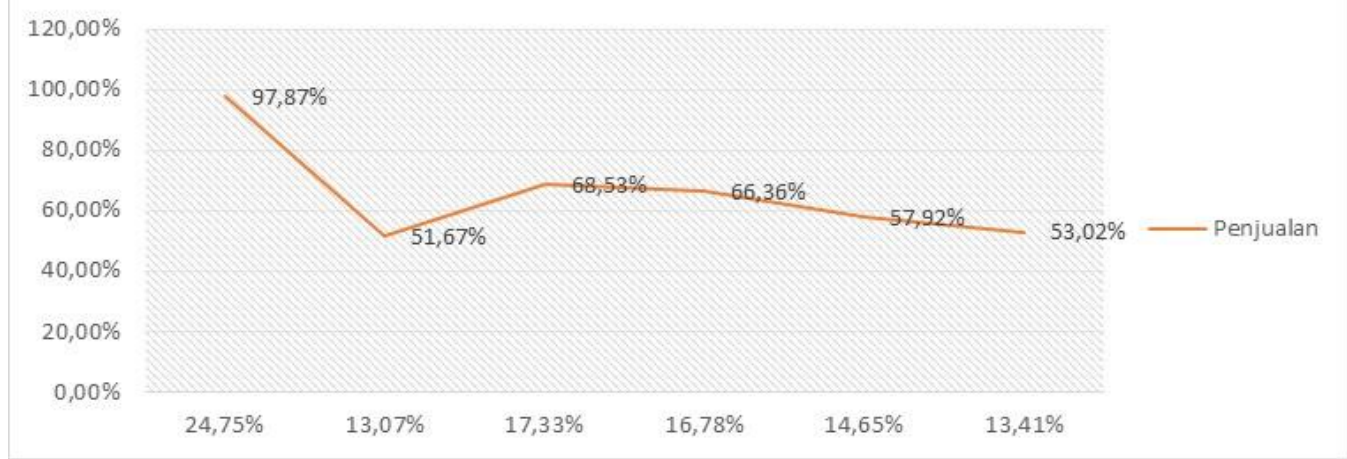

\section{TELAAH PUSTAKA}

\section{Faktor Persepsi}

Persepsi merupakan suatu proses yang timbul akibat adanya sensasi, dimana sensasi adalah aktivitas merasakan atau penyebab keadaan emosi yang menggembirakan. Sensasi juga dapat didefenisikan sebagai tanggapan yang cepat dari indra penerima kita terhadap stimuli dasar, seperti cahaya, warna dan suara (Sangadji, Mamang, 2013).

\section{Kelengkapan produk}

Produk adalah segala sesuatu yang ditawarkan kepada pasar untuk mendapat perhatian, dimiliki, digunakan atau dikonsumsi yang meliputi barang secara fisik, jasa, kepribadian, tempat, organisasi dan gagasan atau buah pikiran (Assauri, 2014). Menurut Kotler (Kotler, Philip dan Amstrong, 2014) Penyediaan kelengkapan produk yang (product assortment) yang baik tidak hanya akan menarik minat tetapi juga dapat mempengaruhi keputusan konsumen untuk berbelanja. Kelengkapan produk merupakan kumpulan seluruh produk dan barang yang ditawarkan penjual tertentu kepada pembeli. Faktor-faktor yang terkandung dalam suatu produk menurut (Assauri, 2014) adalah : Mutu/ kualitas, Pilihan yang ada (option) dan Merek (brand names). Berdasarkan pemikiran dasar tersebut maka dapat dirumuskan hipotesis sebagai berikut:

$H_{1}$ : Kelengkapan produk berpengaruh positif terhadap minat berbelanja Konsumen 


\section{Harga}

Menurut (Assauri, 2014) harga merupakan nilai tukar suatu produk yang dinyatakan dalam satuan moneter dan dapat ditambah dengan produk lainnya. Harga sangat berhubungan dengan nilai dasar dari persepsi konsumen berdasarkan dari keseluruhan unsur bauran pemasaran dalam menciptakan suatu gambaran dan pengalaman bertransaksi. Faktor-faktor yang mempengaruhi harga menurut Assauri (Assauri, 2014) diantaranya adalah: Peraturan pemerintah, Pesaing, Potongan harga (Discount). Berdasarkan pemikiran dasar tersebut maka dapat dirumuskan hipotesis sebagai berikut:

$\mathrm{H}_{2}$ : Harga berpengaruh positif terhadap minat berbelanja Konsumen

\section{Lokasi}

Lokasi menurut (Tjiptono, 2014) Lokasi mengacu pada berbagai aktivitas pemasaran yang berusaha memperlancar dan mempermudah penyampaian atau penyaluran barang dan jasa dari produsen kepada konsumen. Menurut (Huryanti, 2015) beberapa faktor yang mempengaruhi pemilihan lokasi diantaranya adalah :Akses, Visibilitas, Lalu lintas (traffic), Banyak orang yang lalu lalang memberikan peluang besar terjadinya impulse buying dan Kepadatan dan kemacetan lalu lintas dapat pula menjadi hambatan. Berdasarkan pemikiran dasar tersebut maka dapat dirumuskan hipotesis sebagai berikut:

$H_{3}$ : Lokasi berpengaruh positif terhadap minat berbelanja konsumen

\section{Pelayanan}

Menurut (Kotler, Philip dan Amstrong, 2014) pelayanan adalah suatu tindakan atau kinerja yang ditawarkan oleh satu pihak kepada pihak lain dan pada dasarnya tidak berwujud dan tidak melibatkan kepemilikan apapun Menurut (Moenir, 2010) bentuk pelayanan ada tiga macam, yaitu: Pelayanan secara lisan, Pelayanan melalui tulisan dan Pelayanan dengan perbuatan. Berdasarkan pemikiran dasar tersebut maka dapat dirumuskan hipotesis sebagai berikut:

$H_{4}$ : Pelayanan berpengaruh positif terhadap minat berbelanja Konsumen

\section{Kenyamanan}

Menurut (Alma, 2013) menggambarkan konsep kenyamanan bahwa kenyamanan merupakan suatu kondisi perasaan dan sangat tergantung pada orang yang mengalami situasi tersebut. Menurut (Kolcaba, 2010) indikator kenyamanan terdiri dari: Lingkungan, Kondisi, dan Pengaruh dari luar kepada manusia seperti temperatur, warna, suhu. Berdasarkan pemikiran dasar tersebut maka dapat dirumuskan hipotesis sebagai berikut:

$\mathrm{H}_{5}$ : Kenyamanan berpengaruh Positif terhadap minat berbelanja Konsumen 


\section{Minat Beli}

Rossiter dan Perci dalam (Assauri, 2014) mengemukakan bahwa Minat beli merupakan instruksi diri konsumen untuk melakukan pembelian atas suatu produk dengan melakukan perencanaan, mengambil tindakan-tindakan yang relevan seperti mengusulkan, merekomendasikan, memilih dan akhirnya mengambil keputusan untuk melakukan pembelian. Beberapa faktor yang membentuk minat beli konsumen menurut (Kotler, 2012) yaitu Sikap orang lain dan Faktor situasi yang tidak terantisipasi. Berdasarkan pemikiran dasar tersebut maka dapat dirumuskan hipotesis sebagai berikut:

$H_{6}$ : Kelengkapan produk, harga, lokasi, pelayanan dan kenyamanan secara simultan berpengaruh Poisitif terhadap minat berbelanja Konsumen

\section{Gambar 1}

\section{Kerangka Penelitian}

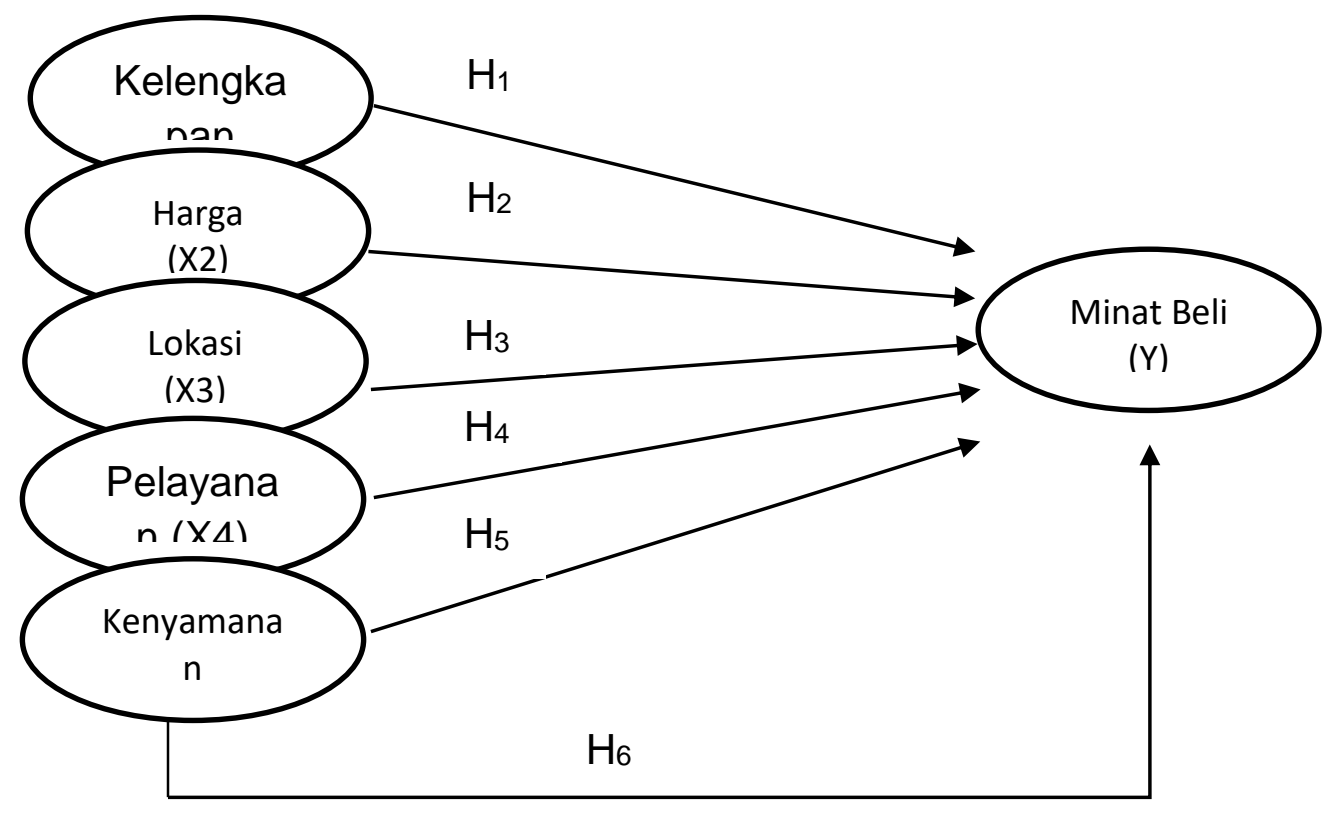

\section{METODE PENELITIAN}

Penelitian ini dilakukan pada konsumen Lotte Grosir Pekanbaru. Populasi pada penelitian ini adalah konsumen yang berbelanja di Lotte Grosir dengan jumlah populasi sebanyak 1.928 orang berdasarkan data pada tahun 2018. Teknik yang digunakan untuk menarik sampel dari populasi menggunakan rumus slovin dengan jumlah 95 orang konsumen. Sedang metode pengambilan sampel dengan menggunakan Accidential Sampling. Definisi Operasional variable dalam penelitian ini adalah Kelengkapan produk $\left(X_{1}\right)$ dengan indikator yaitu : 1) Mutu/ kualitas, 2)Pilihan yang ada (option), 3)Merek (brand names) Sumber (Assauri, 2014). Variabel Harga $\left(\mathrm{X}_{2}\right)$ dengan indikator yaitu: 1)Peraturan pemerintah, 2)Pesaing, 
3)Potongan harga (Discount) Sumber (Assauri, 2014). Variabel Lokasi $\left(X_{3}\right)$ dengan indikator yaitu: 1)Akses, 2)Visibilitas, 3)Lalu lintas (traffic) Sumber (Huryanti, 2015). Variabel Pelayanan $\left(X_{4}\right)$ dengan indikator yaitu: 1)Akses, 2)Visibilitas, 3)Lalu lintas (traffic) Sumber (Moenir, 2010). Variabel Kenyaman ( $\left.X_{5}\right)$ dengan indikator yaitu: 1)Lingkungan, 2)kondisi, 3)Pengaruh dari luar kepada manusia seperti temperatur, warna, suhu sumber (Kolcaba, 2010). Variabel Minat Beli $\left(\mathrm{X}_{6}\right)$ dengan indikator yaitu: 1)Sikap orang lain, 2)Faktor situasi yang tidak terantisipasi sumber (Kotler, Philip dan Amstrong, 2014). Analisis data penelitian melalui beberapa tahapan yaitu: 1) Uji validitas, 2)Uji Reabilitas, 3) Uji Asumsi klasik, 4) Analisis Regresi Linear Berganda, Uji Hipotesis, 5)Koefisien Determinasi (R2). Teknik pengumpulan data menggunakan kuisioner/angket.

\section{HASIL PENELITIAN DAN PEMBAHASAN}

Identitas responden yang menjadi responden dalam penelitian ini diklasifikasikan berdasarkan Usia, jenis kelamin, Status pernikahan, Jenis pekerjaan, dan lama menjadi pelanggan. Adapun Karakteristik responden yang menjadi sampel ditunjukkan pada Grafik 3.

\section{Grafik 3}

\section{Karakteristik Responden}

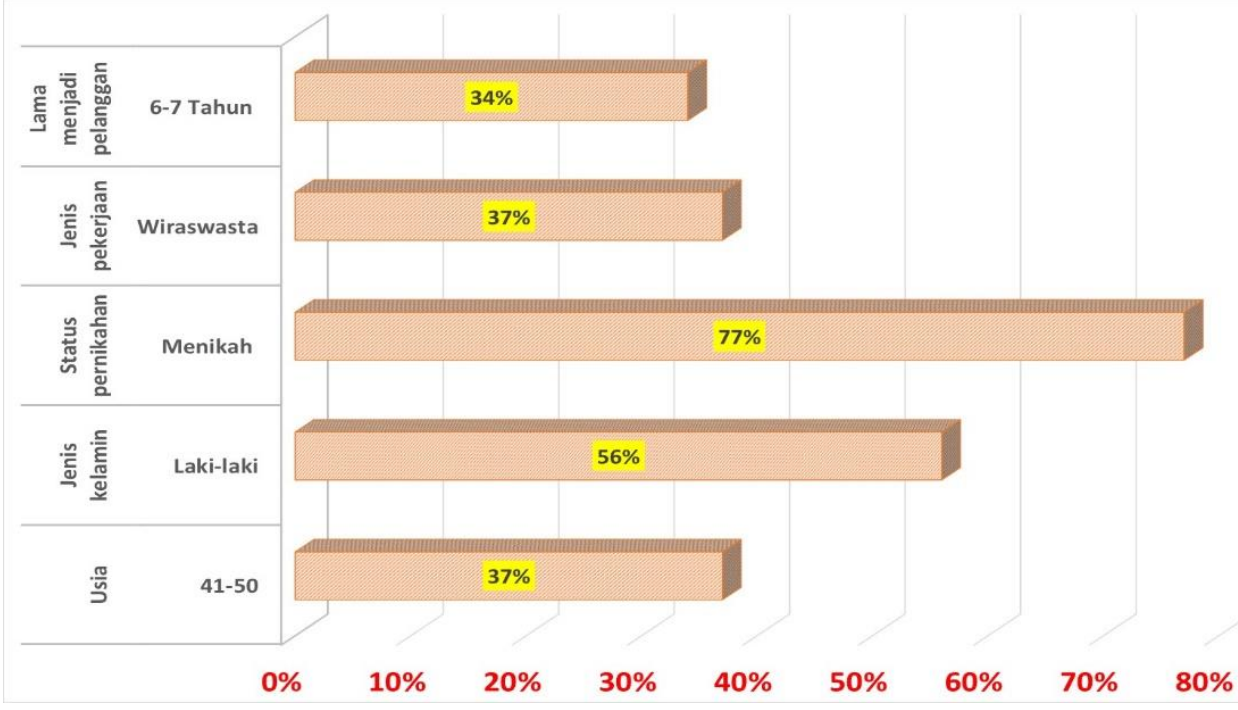

Berdasarkan Grafik 3, diketahui bahwa untuk karakteristik Umur didominasi pada umur 41-50 tahun dengan presentase 37\%. Untuk Jenis kelamin didominasi Laki-laki dengan persentase jawaban 56\%. Status pernikahan didominasi Menikah dengan persentase $77 \%$ sisanya belum minikah. Selanjutnya jenis pekerjaan didominasi dari Wiraswasta dengan persentase $37 \%$ sisanya jenis pekerjaan lain. 
Dan terkahir Lama menjadi pelanggan didominasi di antara 6-7 tahun dengan persentase 34\%.

Dari analisis regresi linier berganda diperoleh koefisien regresi, nilai t hitung dan tingkat signifikansi yang ditampilkan pada Tabel 1. (1) Variabel kelengkapan produk $\left(\mathbf{X}_{1}\right)$ memiliki arah koefisien regresi positif yang menunjukkan adanya pengaruh positif terhadap minat beli $(\mathrm{Y})$ dengan nilai koefisien regresi sebesar 0,484. (2) Variabel Harga $\left(\mathbf{X}_{2}\right)$ memiliki arah koefisien regresi positif yang menunjukkan adanya pengaruh positif terhadap minat beli $(\mathrm{Y})$ dengan nilai koefisien regresi sebesar 0,281 . (3) Variabel Lokasi $\left(\mathbf{X}_{3}\right)$ memiliki arah koefisien regresi positif yang menunjukkan adanya pengaruh positif terhadap minat beli $(Y)$ dengan nilai koefisien regresi sebesar 0,162. (4) Variabel Pelayanan $\left(\mathbf{X}_{\mathbf{4}}\right)$ memiliki arah koefisien regresi positif yang menunjukkan adanya pengaruh positif terhadap minat beli $(Y)$ dengan nilai koefisien regresi sebesar 0,057. (5) Variabel Kenyamanan ( $\mathbf{X}_{5}$ ) memiliki arah koefisien regresi positif yang menunjukkan adanya pengaruh positif terhadap minat beli $(Y)$ dengan nilai koefisien regresi sebesar 0,117. Berdasarkan data diatas maka, dapat di ketahui bahwa variable kelengkapan produk memiliki pengaruh terbesar, sedangkan variabel pelayanan memiliki pengaruh terkecil.

Tabel 1

Hasil Uji Regresi Berganda

\begin{tabular}{ccccccc}
\hline \multicolumn{7}{c}{ Coefficients $^{\mathrm{a}}$} \\
\hline & \multicolumn{2}{c}{$\begin{array}{l}\text { Unstandardized } \\
\text { Coefficients }\end{array}$} & $\begin{array}{c}\text { Standardized } \\
\text { Coefficients }\end{array}$ & $\mathrm{t}$ & Sig. \\
\cline { 2 - 7 } & $\mathrm{B}$ & Std. Error & Beta & & \\
\hline 1 & -1.282 & .265 & & -4.837 & .000 \\
\cline { 2 - 7 } & Model & .412 & .051 & .484 & 8.018 & .000 \\
\cline { 2 - 7 } & Kelengkant) & .202 & .032 & .281 & 6.304 & .000 \\
\hline & .102 & .023 & .162 & 4.464 & .000 \\
\hline Harga X2 & .045 & .037 & .057 & 1.206 & .231 \\
\hline Lokasi X3 & .083 & .033 & .117 & 2.505 & .014 \\
\hline Pelayanan X4 & & & & &
\end{tabular}

Selanjutnya adalah melihat dampak pengaruh secara bersama-sama menggunakan Uji F dengan tujuan untuk mengetahui apakah semua variabel bebas yang dimasukkan dalam model mempunyai pengaruh secara bersama-sama terhadap variabel terikat. Berdasarkan hasil uji ANOVA atau $F_{\text {test }}$ pada Tabel 2 didapatkan nilai $F_{\text {hitung sebesar }} 235,430$ dengan probabilitas 0,000 , karena probabilitasnya jauh lebih kecil dari 0,05 maka model regresi dapat digunakan untuk memprediksi Minat beli ( $Y$ ) atau dikatakan bahwa variabel $X_{1}, X_{2}, X_{3}, X_{4}$, dan $X_{5}$ secara bersama-sama berpengaruh terhadap variabel $\mathrm{Y}$. 
Tabel 2. Hasil Uji F

\begin{tabular}{ccccccc}
\hline \multicolumn{7}{c}{ ANOVA $^{\mathbf{a}}$} \\
\hline \multirow{2}{*}{1} & Sodel & Sum of & Mean & & \\
\hline & Squares & Df & Square & F & Sig. \\
\cline { 2 - 8 } & Residual & 120.138 & 5 & 24.028 & 235.430 & $.000^{\mathrm{b}}$ \\
\cline { 2 - 7 } & Resial & 9.083 & 89 & .102 & & \\
\hline
\end{tabular}

a. Predictors: (Constant), Kelengkapan produk, Harga, Lokasi, Pelayanan, Kenyamanan

b. Dependent Variable : Minat Beli

Uji berikutnya adalah parsial atau Uji t, yaitu suatu uji untuk mengetahui signifikansi pengaruh variabel bebas (Kelengkapan Produk, Harga, Lokasi, pelayanan, dan kenyaman) secara parsial atau individual menerangkan variabel terikat (Minat beli). Hasil analisis Uji t ditunjukkan pada Tabel 1 diatas, sebagai berikut:

(1) Nilai t hitung pada variabel Kelengkapan produk $\left(X_{1}\right)$ adalah sebesar 8,018 dengan tingkat signifikansi 0,000. Karena 8,018 $>1,986$ dan 0,000 $<0,05$ maka $\mathrm{H}_{0}$ ditolak dan $\mathrm{H}_{\mathrm{a}}$ diterima, variabel kelengkapan produk berpengaruh positif dan signifikan terhadap minat beli sesuai dengan penelitian yang dilakukan (Sujoko, 2007) yaitu produk berpengaruh signifikan terhadap keputusan pemakian warnet dikota jember.

(2) Nilai t hitung pada variabel harga $\left(\mathrm{X}_{2}\right)$ adalah sebesar 6,304 dengan tingkat signifikansi 0,000. Karena 6,304 >1,986 dan 0,000 $<0,05$ maka $\mathrm{H}_{0}$ ditolak dan $\mathrm{H}_{\mathrm{a}}$ diterima, variabel harga berpengaruh positif dan signifikan terhadap minat beli . Menurut (Lena Jingen Liang, 2017) dalam penelitianya mengatakan bahwa harga dapat menjadi resiko namun dapat meningkatkan nilai yang dirasakan dan berpengaruh positif terhadap minat beli pada konsumen Airbnb.

(3) Nilai t hitung pada variabel lokasi $\left(X_{3}\right)$ adalah sebesar 4,464 dengan tingkat signifikansi 0,000. Karena 4,464 >1,986 dan $0,000<0,05$ maka $\mathrm{H}_{0}$ ditolak dan $\mathbf{H}_{\mathrm{a}}$ diterima, variabel lokasi berpengaruh positif dan signifikan terhadap minat beli. Menurut (Michael A. Jones, 2003) lokasi merupakan keunggulan bersaing bagi perusahaan ritel.

(4) Nilai t hitung pada variabel pelayanan $\left(X_{4}\right)$ adalah sebesar 1,206 dengan tingkat signifikansi 0,000. Karena 1,206 1,986 dan 0,231 >0,05 maka $\mathbf{H}_{\mathbf{0}}$ ditolak dan $\mathrm{H}_{\mathrm{a}}$ diterima sesuai dengan penelitian yang dilakukan oleh (Muhammad Abid Saleem, Sadaf Zahra, 2017) pada industri penerbangan di Pakistan serta penelitian yang dilakukan (Susanto, 2017) menunjukan kualitas pelayanan berdampak terhadap itensi pembeli produk provider jasa internet di Jakarta

(5) Nilai t hitung pada variabel kenyaman $\left(X_{5}\right)$ adalah sebesar 2,505 dengan tingkat signifikansi 0,000. Karena 2,505 > 1,986 dan 0,231<0,05 maka $\mathrm{H}_{0}$ ditolak dan 
$\mathbf{H}_{\mathbf{a}}$ diterima, namun, variabel kenyamanan berpengaruh positif dan signifikan terhadap minat beli sesuai dengan penelitian (Mohammad Iranmanesh, KrishnaSwamy Jayaraman, 2017) tentang grocery product serta memiliki pengaruh positif terhadap minat beli smartphone di Negeria (Ejechi, 2018).

Tabel 3

Koefisien Determinasi $\left(\mathbf{R}^{2}\right)$

\begin{tabular}{cccccc}
\hline Model & $\mathrm{R}$ & $\mathrm{R}$ Square & \multicolumn{4}{c}{ Model Summary } \\
Squared $\mathrm{R}$ & $\begin{array}{c}\text { Std. Error of the } \\
\text { Estimate }\end{array}$ & Durbin-Watson \\
\hline 1 & $.964 \mathrm{a}$ & .930 & .926 & .319 & 1.830 \\
\hline
\end{tabular}

Pada tabel 3 tersebut juga dapat diketahui bahwa nilai koefisien determinasi berganda (R2) sebesar 0,930. Hal ini menunjukkan bahwa kelima variabel bebas tersebut (kelengkapan produk, harga, lokasi, pelayanan dan kenyamanan) secara bersama-sama memberikan sumbangan atau pengaruh terhadap variabel terikat yaitu minat berbelanja konsumen Lotte Grosir Pekanbaru sebesar 93,00\%, sedangkan sisanya sebesar $17,00 \%$ di pengaruhi oleh variabel-variabel lainnya yang tidak dibahas dalam penelitian ini.

\section{KESIMPULAN DAN IMPLIKASI}

\section{Kesimpulan}

Berdasarkan rumusan masalah pada penelitian ini yaitu apakah persepsi konsumen berpengaruh secara signifikan dan berdampak postif bersama-sama terhadap minat beli. Maka, hasilnya Persepsi konsumen berpengaruh secara simultan secara bersama-sama terhadap minat beli. Namun, secara parsial hanya variabel pelayanan yang tidak memiliki pengaruh sisanya memiliki pengaruh.

\section{Implikasi}

Implikasi teoritis dan manajerial pada penelitian ini adalah diharapkan dapat menambah literatur penelitian tentang pemasaran khususnya tentang persepsi konsumen dan minat beli serta dapat menjadi acuan bagi penelitian-penelitian selanjunya.

\section{Agenda Riset Mendatang}

Keterbatasan dalam penelitian ini adalah jumlah sampel yang masih terbatas. Untuk penelitian selanjunya dapat menambah variable intervening seperti kepuasan konsumen, loyalitas konsumen, keputusan pembelian dan lain-lain. 


\section{REFERENSI}

Alma. (2013). Manajemen Pemasaran dan Pemasaran Jasa. Bandung: Alfabeta. Assauri, S. (2014). Manajemen Pemasaran Dasar. Jakarta: Rajawali pers.

Aufa, J. (2014). 5 Manfaat Belanja Online. Retrieved July 12, 2019, from https://www.liputan6.com/lifestyle/read/2144183/5-manfaat-belanjaonline?related=dable\&utm_expid=.9Z4i5ypGQeGiS7w9arwTvQ.1\&utm_referr er=https\%3A\%2F\%2Fwww.google.com\%2F

Cahya, P. (2018). 10 E-Commerce Terbaik yang Menggeser Eksistensi Toko Offline. Retrieved July 12, 2018, from https://www.idntimes.com/business/ economy/putriana-cahya/10-e-commerce-terbaik-yang-menggeser-eksistensitoko-offline/full

David. (2018). 10 Mall bagus, Besar, Terlengkap di Kota Pekanbaru Ada Bioskop dan Tempat Bermain Anak. Retrieved July 12, 2019, from https://www.jejakpiknik.com/mall-di-pekanbaru/

Ejechi, S. A. A. and J. O. (2018). Modelling repurchase intention among smartphones users in Nigeria. Journal of Modelling in Management, 13(4), 794-814. https://doi.org/https://doi.org/10.1108/JM2-12-2017-0138

Huryanti, R. (2015). Bauran Pemasaran dan Loyalitas Konsumen,. Bandung: Alfabeta.

Kolcaba, K. (2010). An introduction to comfort theory In the comfort line.

Kotler, Philip dan Amstrong, G. (2014). Principles of Marketing. (15th Edition, Ed.). Pearson Education Limited.

Kotler, P. and K. L. K. (2012). Marketing Management (Edisi 14). New Jersey: Prentice-Hall Published.

Lena Jingen Liang, H. C. C. \& M. J. (2017). Understanding repurchase intention of Airbnb consumers: perceived authenticity, electronic word-of-mouth, and price sensitivity. Journal of Travel \& Tourism Marketing. https://doi.org/10.1080/10548408.2016.1224750

Michael A. Jones, D. L. M. and S. E. B. (2003). The effects of locational convenience on customer repurchase intentions across service types. Journal of Services Marketing, 17(7), 701-712. Retrieved from https://www.emerald.com/insight/content/doi/10.1108/08876040310501250/ful l/html

Moenir, A. S. (2010). Manajemen Pelayanan Umum Di Indonesia. Jakarta: Bumi Aksara.

Mohammad Iranmanesh, KrishnaSwamy Jayaraman, S. Z. and S. M. G. (2017). The effects of consumer perception of volume discount benefits on intention to purchase grocery products. Asia Pacific Journal of Marketing and Logistics, 29(5), 1017-1035. 
Muhammad Abid Saleem, Sadaf Zahra, A. Y. (2017). Impact of service quality and trust on repurchase intentions - the case of Pakistan airline industry. Asia Pacific Journal of Marketing and Logistics, 29(5), 1136-1159. https://doi.org/https://doi.org/10.1108/APJML-10-2016-0192

Sangadji, Mamang, E. (2013). Perilaku Konsumen. Yogyakarta: Andi Offset.

Sujoko. (2007). Faktor-faktor yang mempengaruhi keputusan pemakaian jasa warnet di kota jember. Jurnal Manajemen Pemasaran, 2(1), 9-20.

Susanto, A. A. (2017). Faktor Penentu Dari Persepsi Nilai Pelanggan Dan Implikasinya Terhadap Intensi Pembelian. Jurnal Manajemen Dan Pemasaran Jasa, 10(2), 157-170.

Tjiptono, F. (2014). Pemasaran Jasa - Prinsip, Penerapan, dan Penelitian. Yogyakarta: Andi Offset. 